\title{
Katarzyna Święch-Kujawska*
}

\section{CHARAKTER PRAWNY OPLATY REKLAMOWEJ I JEJ ELEMENTY KONSTRUKCYJNE}

\section{Streszczenie}

Daniny publiczne są najistotniejszą kategorią dochodów publicznych. Zalicza się do nich m.in. opłaty, które można zdefiniować jako świadczenia publicznoprawne, przymusowe, bezzwrotne, pieniężne oraz odpłatne. Mogą one stanowić dochody budżetu państwa lub budżetów jednostek samorządu terytorialnego. Jedną z opłat publicznych jest opłata reklamowa. Pobierana jest na podstawie uchwały organu stanowiącego gminy, będąc dochodem własnym gminy. W opracowaniu przedstawiono cechy charakterystyczne wskazanego świadczenia daninowego, przesądzające o jego charakterze prawnym. Zaprezentowano również poszczególne elementy konstrukcyjne opłaty reklamowej. Posłużono się metodą analizy tekstów aktów prawnych, literatury przedmiotu, a także wykorzystano dorobek judykatury. Sformułowano wnioski de lege lata i de lege ferenda.

Słowa kluczowe: danina publiczna, opłata reklamowa, elementy konstrukcyjne

\section{Wprowadzenie}

W 2015 roku weszła w życie ustawa o zmianie niektórych ustaw w związku ze wzmocnieniem instrumentów ochrony krajobrazu ${ }^{1}$. Wskazany akt prawny nie

* dr hab. Katarzyna Święch-Kujawska prof. US, Wydział Prawa i Administracji Uniwersytetu Szczecińskiego, adres e-mail: katarzyna.swiech-kujawska@usz.edu.pl, ORCID 0000-0001-6466-7187.

1 Ustawa z dnia 24 kwietnia 2015 r. (Dz.U. poz. 774 z późn.zm., zwana dalej krajobrazową). 
stanowi zatem kompleksowej, samoistnej regulacji odnoszącej się do tych narzędzi, lecz zmienia inne akty prawne w tym zakresie. Z punktu widzenia zakreślonego tematu najistotniejsze znaczenie ma art. 4 powołanej ustawy, zmieniający ustawę o podatkach i opłatach lokalnych ${ }^{2}$. Istotą tej nowelizacji było wprowadzenie do obrotu prawnego kolejnej daniny publicznej w postaci opłaty reklamowej. Tym samym rozszerzono katalog źródeł dochodów własnych gmin.

Celem opracowania jest określenie charakteru prawnego opłaty reklamowej oraz jej elementów konstrukcyjnych z uwzględnieniem zasad wymiaru i poboru wskazanej daniny publicznej.

\section{Opłata reklamowa jako danina publiczna}

Wszelkie ustalenia dotyczące charakteru prawnego opłaty reklamowej należy poprzedzić ogólnym stwierdzeniem, że samo pojęcie opłaty nie zostało w obecnym porządku prawnym zdefiniowane, chociaż jest powszechnie stosowane tak w ustawodawstwie, jak i doktrynie oraz orzecznictwie. W związku $\mathrm{z}$ tym rozważania w powyższym obszarze należy w pierwszej kolejności odnieść do pojęć o zasadniczym znaczeniu, a mianowicie do szerszej kategorii danin publicznych.

Zgodnie z art. 84 Konstytucji ${ }^{3}$ każdy jest obowiązany do ponoszenia ciężarów i świadczeń publicznych, w tym podatków określonych w ustawie. Pojęcie świadczeń publicznych jest szerokie i obejmuje podatki orazinne daniny publiczne, o których mowa w art. 217 Konstytucji ${ }^{4}$. Z kolei daniny publiczne zostały zdefiniowane przez Trybunał Konstytucyjny ${ }^{5}$ jako świadczenia powszechne, przymusowe, bezzwrotne, ustalane jednostronnie na rzecz podmiotu prawa publicznego w celu realizacji zadań publicznych, a zaliczają się do nich podatki, opłaty administracyjne, cła oraz abonament RTV. Wśród danin publicznych o charakterze pieniężnym wyróżnić można: podatki, opłaty, dopłaty i cła. Wynika z tego, że opłata jest jedną z danin publicznych o charakterze pieniężnym. Nie są to jednak jedyne cechy charakterystyczne dla tego typu świadczenia.

2 Ustawa z dnia 12 stycznia 1991 r. o podatkach i opłatach lokalnych (tekst jedn. Dz.U z 2018 r., poz. 1445 z późn. zm.) - dalej u.p.o.l.

3 Ustawa z dnia 2 kwietnia 1997 r. Konstytucja Rzeczypospolitej Polskiej (Dz.U. nr 78, poz. 483 z późn.zm.).

4 Konstytucja Rzeczypospolitej Polskiej. Komentarz, red. M. Haczkowska, Lex 2014.

5 Wyrok TK z 16 marca 2010 r., sygn. K 24/2008, OTK-A 2010, nr 3, poz. 22. 
Jak wskazano, opłata jest jedną z pieniężnych danin publicznych, w związku z czym dokonuje się jej porównania ze zdefiniowanym na gruncie Ordynacji podatkowej ${ }^{6}$ podatkiem, którego definicja legalna została sformułowana w art. 6 O.p. Stanowi on, że podatkiem jest publicznoprawne, nieodpłatne, przymusowe oraz bezzwrotne świadczenie pieniężne na rzecz Skarbu Państwa, województwa, powiatu lub gminy, wynikające z ustawy podatkowej. Opłata jest daniną różniącą się od podatku jedną, ale podstawową cechą - odpłatnością. Oznacza to, że podmiotowi uiszczającemu ją przysługuje świadczenie wzajemne i ekwiwalentne. O ile bowiem podatek jest świadczeniem, za które nie otrzymuje się bezpośrednio świadczenia wzajemnego, to przedmiotem opłaty jest świadczenie w interesie obywatela, wyrażane w drodze zachowania się (działania) organu państwa (samorządu) 7 . Bez znaczenia pozostaje przy tym to, czy podmioty uiszczające opłatę żądały podjęcia określonych czynności przez organy publicznoprawne, czy też do korzystania z nich zostały prawnie zobligowane ${ }^{8}$. Wynika z tego jednoznacznie, że najistotniejszą cechą odróżniającą opłatę od innych publicznych danin pieniężnych jest jej odpłatność. Należy zauważyć, że w literaturze przedmiotu wyrażono również pogląd, że cecha odpłatności nie powinna być utożsamiana z ekwiwalentnością. Odpłatność zakłada bowiem wzajemność i jest atrybutem opłat publicznoprawnych. Natomiast ekwiwalentność jest cechą cywilistyczną i ekonomiczną, a opłaty ekwiwalentne odpowiadają kategorii ceny i należy rozpatrywać je w aspektach cywilnoprawnych, zwłaszcza jeśli nie mają przymusowego charakteru ${ }^{9}$.

Uwzględniając powyższe ustalenia wydaje się, że opłatę można zdefiniować jako odpłatne, bezzwrotne, przymusowe świadczenie pieniężne na rzecz Skarbu Państwa, powiatu lub województwa nałożone w drodze ustawowej. Bezzwrotność oznacza definitywne przeniesienie własności środków pieniężnych. Zwrot uiszczającemu możliwy jest jedynie w sytuacji nienależnego poboru lub uiszczenia daniny w wysokości wyższej od należnej. Przymusowy charakter jest następstwem władztwa państwowego i w najogólniejszym ujęciu polega na możliwości

6 Ustawa z dnia 29 sierpnia 1997 r. Ordynacja podatkowa (tekst jedn. Dz.U. z 2018 r., poz. 800 z późn.zm.) - dalej O.p.

7 L. Adam, M. Mazurkiewicz, Opłaty, w: System instytucji prawno-finansowych PRL, t. III, red. M. Weralski, Wrocław-Warszawa-Kraków-Gdańsk-Lódź 1985, s. 471.

8 J. Gliniecka, Opłaty publiczne w Polsce. Analiza prawna i funkcjonalna, BydgoszczGdańsk 2007, s. 14.

9 E. Ruśkowski, J. Salachna, Ustawa o dochodach jednostek samorządu terytorialnego. Komentarz, Warszawa 2004, s. 86. 
zastosowania środków przymusu w celu wyegzekwowania należnego świadczenia. Egzekucja dokonywana jest na zasadach i w granicach określonych przez prawo. Wysokość opłaty musi być każdorazowo wyrażona określoną kwotą pieniężną, co jest tożsame z pieniężnym charakterem daniny. Przyjmuje się że o charakterze daniny publicznej świadczy nie jej nazwa, a powyżej wskazane cechy ${ }^{10}$.

Warto również odnotować, że możliwe jest wyróżnienie trzech rodzajów opłat. Kryterium tej typizacji stanowi ustalenie relacji wartości świadczeń podmiotów - zobowiązanego i uprawnionego. Na jego podstawie można wyodrębnić opłaty, w których:

a) świadczenia obu podmiotów są w pełni ekwiwalentne - prawidłowo została ustalona wysokość opłaty w stosunku do wartości świadczenia wzajemnego;

b) świadczenia obu podmiotów nie są w pełni ekwiwalentne, zachodzi dysproporcja między opłatą a „wyceną” świadczenia - w takim przypadku zazwyczaj opłata jest zbyt wygórowana w stosunku do świadczonej usługi i ma wówczas w części charakter podatku;

c) świadczenia podmiotów nie są w ogóle ekwiwalentne - uiszczający opłatę w zasadzie nie może liczyć na świadczenie wzajemne bądź jego wartość jest znikoma; taka opłata jest podatkiem „ukrytym” pod inną nazwą.

Odnosząc przedstawione uwagi do opłaty reklamowej, można mieć wątpliwości dotyczące wyznaczenia jej miejsca w systemie opłat lokalnych. Nie sposób bowiem wskazać na ekwiwalentność tej daniny ${ }^{11}$. Nie można jej wywodzić z samej możliwości sytuowania reklam na zasadach określonych w prawie miejscowym.

Oceny charakteru prawnego świadczenia można również dokonywać przez pryzmat celów regulacji ${ }^{12}$. Słuszne jest więc odniesienie się do uzasadnienia do ustawy krajobrazowej, w którym stwierdzono, że opłata za umieszczenie reklam ma stanowić jedno $\mathrm{z}$ narzędzi porządkowania przestrzeni publicznej, a możliwość pozyskania dodatkowych dochodów z tego tytułu powinna przysługiwać jedynie tym gminom, które podejmują działania zmierzające w tym kierunku. Uogólniając, można stwierdzić, że wprowadzenie tej daniny pozostaje w ścisłym związku z motywami uchwalenia ustawy krajobrazowej,

10 Por. A. Krzywoń, Podatki $i$ inne daniny publiczne $w$ orzecznictwie Trybunału Konstytucyjnego. Najnowsze tendencje, „Przegląd Sejmowy” 2012, nr 1, s. 32.

11 Por. M. Hadel, Oplata reklamowa jako instrument ksztaltowania gminnej polityki przestrzennej, „Finanse Komunalne” 2016, nr 7-8, s. 88.

12 Por. D. Antonów, Charakter prawny opłaty reklamowej, „Finanse Komunalne” 2017, nr 1-2, s. 106. 
a opłata ma przede wszystkim służyć realizacji celów pozafiskalnych, zwłaszcza regulacyjnych (ograniczanie lub eliminacja reklam z przestrzeni publicznej). Należy przy tym zgodzić się ze stanowiskiem, że występuje tu pewien paradoks. Skoro świadczenie ma służyć wyeliminowaniu reklam z przestrzeni publicznej, to jednocześnie realizacja tego celu eliminuje przedmiot tej opłaty i tym samym eliminuje wpływy z jej tytułu. Jeśli więc ustawodawcy udałoby się osiągnąć zamierzony skutek (oczyszczenie krajobrazu z reklam), to wyeliminowany zostałby również jeden z elementów stanu faktycznego powodującego powstanie obowiązku z tytułu tej opłaty ${ }^{13}$.

Reasumując, należy stwierdzić, że opłata reklamowa jest szczególnego rodzaju daniną publiczną, zbliżoną do podatku, a u podstaw jej wprowadzenia leżą cele pozafiskalne.

\section{Konstrukcja prawna opłaty reklamowej}

Zagadnienie konstrukcji prawnej opłaty reklamowej obejmuje wiele kwestii. Ich omówienie wymaga przyjęcia pewnej systematyki sprzyjającej przejrzystości rozważań. $Z$ tego punktu widzenia zasadna jest charakterystyka daniny przez pryzmat jej elementów konstrukcyjnych. W świetle art. 217 Konstytucji nakładanie podatków, innych danin publicznych, określanie podmiotów, przedmiotów opodatkowania i stawek podatkowych, a także zasad przyznawania ulg i umorzeń oraz kategorii podmiotów zwolnionych od podatków następuje w drodze ustawy. Powołany przepis stanowi nie tylko gwarancję ochrony praw podatnika, ale również wyraża zasadę władztwa podatkowego ${ }^{14}$.

Przed przystąpieniem do pogłębionej analizy poszczególnych komponentów struktury opłaty należy jednak odnieść się do ogólnych dotyczących jej zasad. Przede wszystkim należy zauważyć, że uchwała wprowadzająca opłatę reklamową jest integralnie związana $\mathrm{z}$ innym aktem prawa miejscowego, a mianowicie z uchwałą określającą zasady i warunki sytuowania obiektów małej architektury, tablic reklamowych i urządzeń reklamowych oraz ogrodzeń. Zgodnie bowiem $z$ art. 17a u.p.o.l, danina ta może być pobierana jedynie na obszarach, dla których obowiązują te zasady i warunki. Te ostatnie z kolei również mają charakter fakultatywny, a możliwość ich określenia została wprowadzona

13 Ibidem, s. 108.

14 Por. wyrok NSA z 20 czerwca 2017 r., sygn. IFSK 997/15, LEX 2337592. 
do porządku prawnego na mocy art. 7 ustawy krajobrazowej, zmieniającej w tym zakresie ustawę o planowaniu i zagospodarowaniu przestrzennym ${ }^{15}$ (dalej jako u.p.z.p.). W związku z tym wprowadzenie do obrotu prawnego regulacji daninowych jest bezpośrednio warunkowane podjęciem innej uchwały, również o charakterze fakultatywnym.

Podstawę prawną do uchwalenia tego aktu prawa miejscowego stanowi art 37a u.p.z.p., a określa się w nim zasady i warunki sytuowania obiektów małej architektury, tablic reklamowych i urządzeń reklamowych oraz ogrodzeń, ich gabaryty, standardy jakościowe oraz rodzaje materiałów budowlanych, z jakich mogą być wykonane (dalej: „uchwała dotycząca małej architektury”). W odniesieniu do szyldów określa się zasady i warunki ich sytuowania, gabaryty oraz liczbę szyldów, które mogą być umieszczone na danej nieruchomości przez podmiot prowadzący na niej działalność. Organowi stanowiącemu gminy przyznano też możliwość, w podjętej uchwale, ustalenia zakazu sytuowania ogrodzeń oraz tablic reklamowych i urządzeń reklamowych z wyłączeniem szyldów. Oprócz tego w szczegółowy sposób ustawowo uregulowano kwestie zakresu terytorialnego obowiązywania uchwały. Z praktycznego punktu widzenia istotne jest przyznanie możliwości różnicowania regulacji prawnych obowiązujących dla różnych obszarów gminy, pod warunkiem jednak jednoznacznego określenia granic tych wydzielonych obszarów. Jak wynika z przedstawionych regulacji prawnych, ich wprowadzenie do obrotu prawnego poszerza władztwo planistyczne gminy, a regulacje będące przedmiotem regulacji uchwał mają charakter bardziej szczegółowy niż ustalenia miejscowego planu zagospodarowania przestrzennego ${ }^{16}$. Należy też zaakcentować, że procedura przygotowania projektu charakteryzowanej uchwały jest mniej skomplikowana niż procedura przygotowania miejscowego planu zagospodarowania przestrzennego ${ }^{17}$.

Z postanowień ustawy wywieść też można wniosek, że przyjęte rozwiązania prawne wprowadzają prymat ochrony krajobrazu nad dotychczas nabytymi prawami polegającymi na usytuowaniu obiektu reklamowego, co stanowi swoiste novum w systemie aktów planowania przestrzennego ${ }^{18}$.

15 Ustawa z dnia 27 marca 2003 r. o planowaniu i zagospodarowaniu przestrzennym (tekst jedn. Dz.U. z 2018 r., poz. 1945).

16 T. Brzezicki, Kara za niezgodne z prawem umieszczenie reklamy, „Przegląd Podatkowy” 2016, nr 8, s. 36.

17 Por. A. Nałęcz, Estetyka przestrzeni publicznej w samorządzie terytorialnym, „Samorząd Terytorialny" 2015 , nr 11, s. 8.

18 T. Brzezicki, op. cit., s. 36. 
W kwestii zależności pomiędzy ustanawianiem uchwały dotyczącej małej architektury a możliwością wprowadzenia opłaty reklamowej można mieć wątpliwości, czy wprowadzenie opłaty wymaga podjęcia odrębnej uchwały podatkowej, czy też możliwe jest usytuowanie jej w uchwale dotyczącej małej architektury. Godne aprobaty jest stanowisko, zgodnie z którym opłata reklamowa powinna być przedmiotem regulacji odrębnej uchwały, co niewątpliwie przyczyni się do zwiększenia przejrzystości i czytelności prawa miejscowego oraz umożliwi rozgraniczenie polityki zagospodarowania przestrzennego od polityki fiskalnej gmin ${ }^{19}$. Taki wniosek można wyprowadzić również z postulatu regulacji materii daninowej w odrębnych aktach prawnych. Niewykluczone jest jednak wprowadzenie obu tych regulacji w drodze jednej uchwały (będzie ona miała wówczas charakter mieszany). W każdym przypadku konieczne jest jednak zachowanie chronologii uchwalania tych aktów prawa miejscowego. Niedopuszczalne byłoby podjęcie uchwały daninowej przed uchwałą statuującą możliwość jej podjęcia (uchwałą dotyczącą małej architektury) ${ }^{20}$.

Równie istotną kwestią ogólną jest fakultatywny charakter omawianej opłaty. Wynika on wprost z art. 17a u.p.o.l., zgodnie z którym rada gminy może wprowadzić opłatę reklamową. Przyjęcie takiego rozwiązania odzwierciedla ogólne tendencje do poszerzania zakresu władztwa daninowego jednostek samorządu terytorialnego o możliwość odstąpienia od uchwalania opłat lokalnych regulowanych powołaną ustawą. W aktualnie obowiązującym stanie prawnym wprowadzenie wszystkich tego typu świadczeń pozostawiono w gestii organów stanowiących gminy. Jest to racjonalne, zwłaszcza ze względu na możliwość prowadzenia lokalnej polityki daninowej i efektywność realizacji opłat.

Przechodząc do analizy elementów konstrukcji charakteryzowanej daniny publicznej, w pierwszej kolejności należy określić jej zakres przedmiotowy. Zgodnie z literalnym brzmieniem art. 17a u.p.o.l, rada gminy może wprowadzić opłatę reklamową od umieszczonych tablic reklamowych lub urządzeń reklamowych. Wynika z tego, że zakres przedmiotowy obejmuje samo umieszczenie wskazanych nośników, bez względu na to, czy są one faktycznie wykorzystywane (czy zawierają jakiekolwiek treści). Nie rozstrzygnięto poza tym kwestii, czy obowiązek uiszczenia opłaty reklamowej powstaje

19 M. Hadel, op. cit., s. 87.

20 Ustawa krajobrazowa. Komentarz do przepisów wprowadzonych $w$ zwiąku ze wzmocnieniem narzędzi ochrony krajobrazu, red. A. Fogel, Warszawa 2016, s. 74. 
również w przypadku umieszczenia tablic lub urządzeń reklamowych niezgodnie z zasadami przyjętymi w uchwale podjętej przez radę gminy ${ }^{21}$. Na tak postawione pytanie należy odpowiedzieć twierdząco. Odpowiedzialność za niezgodne z przyjętymi regułami lokowanie reklamy wydaje się niezależna od obowiązku daninowego.

Mówiąc o zakresie przedmiotowym, nie można pominąć zasadniczej kwestii dotyczącej zdefiniowania przedmiotu opłaty. Ustawodawca w tym zakresie odsyła do ustawy o planowaniu i zagospodarowaniu przestrzennym, w której zdefiniowano te pojęcia. Tablicą reklamową, w myśl powołanej ustawy, jest przedmiot materialny przeznaczony lub służący ekspozycji reklamy wraz z jego elementami konstrukcyjnymi i zamocowaniami, o płaskiej powierzchni służącej ekspozycji reklamy, w szczególności baner reklamowy, reklama naklejana na okna budynków i reklamy umieszczane na rusztowaniu, ogrodzeniu lub wyposażeniu placu budowy, z wyłączeniem drobnych przedmiotów codziennego użytku wykorzystywanych zgodnie z ich przeznaczeniem. Wynika z tego, że katalog przedmiotów uznawanych za tablicę reklamową ma charakter katalogu otwartego. $\mathrm{Z}$ kolei urządzenie reklamowe zdefiniowano jako przedmiot materialny przeznaczony lub służący ekspozycji reklamy wraz z jego elementami konstrukcyjnymi ${ }^{22}$ i zamocowaniami, inny niż tablica reklamowa, z wyłączeniem drobnych przedmiotów codziennego użytku wykorzystywanych zgodnie z ich przeznaczeniem. Warto odnotować, że w ustawie o planowaniu i zagospodarowaniu przestrzennym zdefiniowano również pojęcie „reklama”. Odnosi się ją do upowszechniania w jakiejkolwiek wizualnej formie informacji promującej osoby, przedsiębiorstwa, towary, usługi, przedsięwzięcia lub ruchy społeczne. Potwierdza to, że ustawodawca obowiązkiem daninowym objął w istocie posadowienie w przestrzeni publicznej nośników reklamy (co wynika również bezpośrednio $\mathrm{z}$ treści art. 17 ust 3 in fine). Podkreślić przy tym należy, że wobec wyczerpująco określonego i zdefiniowanego ich katalogu poszerzenie zakresu przedmiotowego opłaty, na zasadzie analogii, o inne przedmioty (np. pojazdy mechaniczne) uznać należy za niezgodne $\mathrm{z}$ ustawą̨ ${ }^{23}$.

21 Por. D. Antonów, op. cit., s. 109.

22 Elementem konstrukcyjnym planszy reklamowej jest również jej „obudowa”, por. wyrok WSA z 6 lutego 2013 r., sygn. III SA/Po 1124/12, www.nsa.gov.pl (dostęp 30.03.2019).

23 Por. wyrok WSA z 11 sierpnia 2017 r., sygn. IISA/Łd 523/17, Lex nr 2353893; wyrok NSA 24 marca 2009 r., sygn. II GSK 812/08, Lex nr 529874; wyrok WSA z 25 sierpnia 2016 r., sygn.VI SA/Wa 554/16, Lex nr 2185936; wyrok NSA z 12 grudnia 2018 r., sygn. II FSK 1897/18, www.nsa.gov.pl (dostęp 30.03.2019). 
Istotne znaczenie ma ustawowo określony katalog wyłączeń z opłaty niektórych nośników. Świadczenia nie pobiera się, jeżeli nośniki te:

1) nie są widoczne z przestrzeni dostępnych publicznie;

2) stanowią szyld, o ile jest on zgodny z zasadami i warunkami sytuowania obiektów małej architektury, tablic reklamowych i urządzeń reklamowych oraz ogrodzeń. Pod pojęciem szyldu należy rozumieć tablicę reklamową lub urządzenie reklamowe informującą o działalności prowadzonej na nieruchomości, na której ta tablica reklamowa lub urządzenie reklamowe się znajdują;

3) są realizacją obowiązku nałożonego przepisami prawa;

4) służą wyłącznie do upowszechniania informacji:

a) trwale upamiętniającej osoby, instytucje lub wydarzenia,

b) o charakterze religijnym, związanym z działalnością kościołów lub innych związków wyznaniowych, jeżeli tablica reklamowa lub urządzenie reklamowe sytuowane są $\mathrm{w}$ granicach terenów użytkowanych jako miejsca kultu i działalności religijnej oraz cmentarzy.

Analiza przywołanych wyłączeń prowadzi do wniosku o diametralnie różnych motywach oraz warunkach ich wprowadzenia i stosowania. Wydaje się, że pierwsze z wymienionych odstępstw od zasad ogólnych najściślej nawiązuje do przyczyn wprowadzenia opłaty, którą jest kształtowanie krajobrazu. Równocześnie kwestia „widoczności z przestrzeni publicznej” w praktyce może nastręczać wielu wątpliwości natury ocennejej ${ }^{24}$.

W tym miejscu zasadne jest wskazanie, że wyłączenia te mają charakter ustawowy, a ich powielenie w uchwałach dotyczących opłaty reklamowej jest co najmniej bezcelowe ${ }^{25}$. Powtórzony przepis może być interpretowany przez przeciętnego odbiorcę jako regulacja prawa miejscowego, co może prowadzić do niejasności oraz częściowego wypaczenia intencji ustawodawcy ${ }^{26}$.

Zakres podmiotowy opłaty jest skorelowany z jej zakresem przedmiotowym. W myśl art. 17a ust. 3 u.p.o.l., pobiera się ją od:

1) właścicieli nieruchomości lub obiektów budowlanych, z wyłączeniem nieruchomości gruntowych oddanych w użytkowanie wieczyste;

24 Por. D. Antonów, op. cit., s. 110.

25 Por. S. Wronkowska, M. Zieliński, Komentarz do zasad techniki prawodawczej z dnia 20 czerwca 2002 r., Warszawa 2012, s. 277, 272, 240.

26 Por. wyrok WSA z 12 marca 2012 r., sygn. II SA/Bd 1373/11, www.nsa.gov.pl; wyrok WSA z 19 lutego 2009 r., sygn. I SA/Kr 1106/08, www. nsa.gov.pl; wyrok WSA z 6 grudnia 2006 r., sygn. II SA/Gl 662/06, www.nsa.gov.pl; wyrok WSA z 20 maja 2008 r., sygn. II SA/Wr 204/08, www.nsa.gov.pl (dostęp 30.03.2019). 
2) użytkowników wieczystych nieruchomości gruntowych;

3) posiadaczy samoistnych nieruchomości lub obiektów budowlanych;

4) posiadaczy nieruchomości lub ich części albo obiektów budowlanych lub ich części, stanowiących własność Skarbu Państwa lub jednostki samorządu terytorialnego, jeżeli posiadanie:

a) wynika z umowy zawartej z właścicielem, Krajowym Ośrodkiem Wsparcia Rolnictwa lub z innego tytułu prawnego,

b) jest bez tytułu prawnego.

Przedstawione wyliczenie świadczy o objęciu obowiązkiem zapłaty podmiotu faktycznie władającego nieruchomością. Jest to rozwiązanie analogiczne do obowiązującego w podatku od nieruchomości. Trudno wprawdzie mówić o majątkowym charakterze opłaty, tym niemniej obowiązek jej zapłaty łączony jest z władaniem nieruchomością, a nie własnością nośnika reklamy (przy założeniu, że nie stanowi on części składowej nieruchomości). Bez znaczenia pozostaje również stosunek prawny łączący wymienionego władającego nieruchomością i właściciela tablicy reklamowej lub urządzenia reklamowego. Wszelkie postanowienia umowne pomiędzy tymi podmiotami w zakresie obowiązku ponoszenia ciężaru publicznoprawnego nie wywołują skutków prawnych w postaci przeniesienia obowiązku daninowego. Ewentualne postępowanie egzekucyjne będzie prowadzone wobec podmiotu wskazanego w ustawie o podatkach i opatach lokalnych. Jednocześnie należy zauważyć, że ustawodawca powinien jednoznacznie doprecyzować, wzorem podatku od nieruchomości, że w przypadku gdy nieruchomość znajduje się w posiadaniu samoistnym, obowiązek daninowy ciąży na posiadaczu samoistnym.

Postanowieniami ustawy rozstrzygnięto natomiast kwestię współwłasności lub współposiadania nieruchomości lub obiektu budowlanego, na których zlokalizowana jest tablica reklamowa lub urządzenie reklamowe. W takim przypadku obowiązek w zakresie wniesienia opłaty reklamowej ciąży solidarnie odpowiednio na wszystkich współwłaścicielach lub współposiadaczach. Regulację tę należy ocenić jednoznacznie pozytywnie.

Godne aprobaty jest również wprowadzenie ustawowej zasady, w myśl której kwotę zapłaconego podatku od nieruchomości od tablicy reklamowej lub urządzenia reklamowego, zalicza się na poczet opłaty reklamowej należnej od tej tablicy reklamowej lub urządzenia reklamowego. Komentując przytoczony przepis, należy zwrócić uwagę na następujące kwestie. Ratio legis wprowadzonego rozwiązania prawnego była eliminacja podwójnego opodatkowania budowli 
będących równocześnie tablicami reklamowymi ${ }^{27}$. Przyjęcie tej skądinąd słusznej zasady może prowadzić do istotnych problemów w praktyce jej stosowania. Mogą one być związane przede wszystkim z ustaleniem tego, jaka część $\mathrm{z}$ wykazanej $\mathrm{w}$ deklaracji podatkowej $\mathrm{w}$ zakresie podatku od nieruchomości wartości budowli ogółem stanowi część podlegającą zaliczeniu na poczet opłaty reklamowej. Można w tym zakresie wnioskować o dokonanie przez radę gminy odpowiednich zmian deklaracji w podatku od nieruchomości, polegających na wyodrębnieniu w grupie budowli podgrupy tablic reklamowych i urządzeń reklamowych. Rozważyć można byłoby dodatkowo wprowadzenie przez radę gminy do deklaracji w zakresie opłaty reklamowej obowiązku złożenia informacji o wysokości zapłaconego od tablic reklamowych lub urządzeń reklamowych podatku od nieruchomości, a zatem danych niezbędnych do wymiaru i poboru opłaty reklamowej ${ }^{28}$.

W specyficzny sposób ustawodawca określił sposób wyliczenia wysokości opłaty reklamowej. Charakterystyczne jest przy tym ustawowe przyjęcie zasad, które nie mogą być korygowane postanowieniami uchwał organów stanowiących jednostek samorządu terytorialnego. Podstawowe znaczenie ma postanowienie, zgodnie z którym opłata reklamowa składa się z dwóch części: stałej i zmiennej. Część stała ma zryczałtowaną wysokość, niezależną od pola powierzchni tablicy reklamowej lub urządzenia reklamowego służącego ekspozycji reklamy. Część zmienna natomiast jest uzależniona od wielkości pola powierzchni tablicy lub urządzenia reklamowego służących ekspozycji reklamy. Jeżeli natomiast kształt urządzenia reklamowego uniemożliwia wyznaczenie pola powierzchni służącej ekspozycji reklamy, to przyjmuje się, że wysokość opłaty zależy od pola powierzchni bocznej prostopadłościanu opisanego na urządzeniu reklamowym.

W pełni należy podzielić pogląd, że wyodrębnienie dwóch części opłaty stanowi próbę zróżnicowania jej wysokości ze względu na stopień ingerencji tablicy lub urządzenia reklamowego w krajobraz, przy jednoczesnym zachowaniu powszechności świadczenia ${ }^{29}$.

O należnej kwocie opłaty reklamowej decyduje, oprócz swoistej podstawy jej wyliczenia, także stawka tej daniny publicznej. W tym zakresie przyjęto reguły analogiczne do pozostałych, stosowanych w ustawie o podatkach i opłatach lokal-

27 B. Pahl, Podatki i opłaty lokalne. Teoria i praktyka, Lex 2017 (dostęp 1.12.2018).

28 P. Borszowski, K. Stelmaszczyk, Komentarz do ustawy o podatkach i opłatach lokalnych, w: Podatki i optaty lokalne. Podatek rolny. Podatek leśny. Komentarz, Lex 2016 (dostęp 1.12.2018).

29 D. Antonów, op. cit., s. 111. 
nych. Oznacza to, że rada gminy, w drodze uchwały, określa wysokość stawek opłaty reklamowej, z tym że stawka części stałej opłaty reklamowej nie może przekroczyć w 2019 roku $^{30}$ 2,54 zł dziennie, a stawka części zmiennej opłaty reklamowej nie może przekroczyć w 2019 roku 0,22 zł od $1 \mathrm{~m}^{2}$ pola powierzchni tablicy reklamowej lub urządzenia reklamowego służących ekspozycji reklamy dziennie. Jednoznacznie wynika z tego, że stawki mają charakter stawek stałych wyrażonych kwotowo. Organowi stanowiącemu gminy zagwarantowano pewien dozwolony konstytucyjnie zakres władztwa podatkowego polegający na możliwości kształtowania wysokości opłaty w granicach ustawowych. Zauważyć przy tym należy, że górne granice stawek opłat lokalnych obowiązujące w danym roku podatkowym ulegają corocznie zmianie na następny rok podatkowy w stopniu odpowiadającym wskaźnikowi cen towarów i usług konsumpcyjnych ${ }^{31} \mathrm{w}$ okresie pierwszego półrocza roku, w którym stawki ulegają zmianie, w stosunku do analogicznego okresu roku poprzedniego. Minister właściwy do spraw finansów publicznych ogłasza, w drodze obwieszczenia, w Dzienniku Urzędowym Rzeczypospolitej Polskiej „Monitor Polski” górne granice stawek kwotowych na każdy rok podatkowy z uwzględnieniem powyższej zasady, zaokrąglając je w górę do pełnych groszy.

Istotne znaczenie dla omawianej problematyki ma ustawowa reguła, zgodnie z którą w przypadku nieuchwalenia stawek opłat lokalnych stosuje się stawki obowiązujące $\mathrm{w}$ roku poprzedzającym rok podatkowy. O ile zasadność przedstawionej formuły nie budzi istotniejszych wątpliwości interpretacyjnych i zastrzeżeń w stosunku do obligatoryjnych podatków lokalnych, o tyle można mieć wątpliwości co do zasadności jej stosowania wobec fakultatywnych opłat lokalnych (w tym opłaty reklamowej). Wydaje się bowiem, że rada gminy decydując się na wprowadzenie opłaty reklamowej, powinna corocznie korzystać z przyznanego jej władztwa daninowego.

Na uwagę zasługuje również szeroki katalog spraw, które powinny zostać uregulowane w uchwale daninowej podjętej przez radę gminy. Należy jednocześnie uznać, że niektóre z nich stanowią warunek sine qua non realizacji dochodów z opłaty reklamowej. Przede wszystkim organ stanowiący jednostki samorządu terytorialnego powinien określić (oprócz stawek) zasady ustalania i poboru oraz

30 Stawki określone w obwieszczeniu Ministra Finansów z dnia 25 lipca 2018 r. w sprawie górnych granic stawek kwotowych podatków i opłat lokalnych na rok 2019 (MP z 2018 r., poz. 745).

31 Wskaźnik ten ustala się na podstawie komunikatu Prezesa Głównego Urzędu Statystycznego ogłoszonego w Dzienniku Urzędowym Rzeczypospolitej Polskiej „Monitor Polski” w terminie 20 dni po upływie pierwszego półrocza. 
terminy płatności daniny. Oprócz tego organ ten został wyposażony w możliwość zarządzenia poboru opłaty w drodze inkasa oraz określenia inkasentów i wysokości wynagrodzenia za inkaso, wprowadzenia innych niż wymienione w ustawie zwolnień przedmiotowych. To ostatnie upoważnienie jest na tyle nieprecyzyjne, że można mieć istotne wątpliwości, czy „niepobieranie” opłaty od wymienionych $\mathrm{w}$ art. 17a ust 5 ustawy tablic i urządzeń reklamowych powinno być traktowane jako katalog zwolnień, czy raczej wyłączeń z opłaty. Niezależnie jednak od przyjętej terminologii rada gminy może wprowadzać zwolnienia przedmiotowe z opłaty reklamowej. Za istotną, z praktycznego punktu widzenia, kompetencję należy również uznać uprawnienie do różnicowania wysokości stawek opłaty reklamowej z uwzględnieniem lokalizacji oraz wielkości lub rodzaju tablicy reklamowej lub urządzenia reklamowego.

Rada gminy, w drodze uchwały, może także wprowadzić obowiązek składania organowi podatkowemu właściwemu ze względu na miejsce położenia tablic reklamowych lub urządzeń reklamowych deklaracji na opłatę reklamową, a także określić termin, warunki i tryb składania tych deklaracji (w tym przypadku rada gminy określa wzór formularza deklaracji na opłatę reklamową, w którym zawarte będą dane dotyczące podmiotu i przedmiotu opodatkowania niezbędne do wymiaru i poboru opłaty reklamowej) oraz wprowadzić możliwość składania deklaracji na opłatę reklamową za pomocą środków komunikacji elektronicznej.

\section{Podsumowanie}

Charakteryzowana w opracowaniu opłata reklamowa stanowiąca dochód własny gminy jest daniną publiczną, której pobór jest możliwy od września 2015 roku. Uregulowana przepisami ustawy o podatkach i opłatach lokalnych wykazuje zarówno cechy charakterystyczne dla pozostałych opłat normowanych powołanym aktem prawnym, jak i cechy świadczące o jej specyfice. Do tych ostatnich zaliczyć należy przede wszystkim komplementarny charakter uchwały w sprawie opłaty reklamowej. Wprowadzenie opłaty do obrotu prawnego uzależniono bowiem od wcześniejszego podjęcia przez organy stanowiące gminy uchwały dotyczącej zasad i warunków sytuowania obiektów małej architektury, tablic reklamowych i urządzeń reklamowych oraz ogrodzeń, ich gabarytów, standardów jakościowych oraz rodzajów materiałów budowlanych, z jakich mogą być wykonane. Pozwala to równocześnie na sformułowanie wniosku, że podstawową funkcją tej daniny jest funkcja regulacyjna, która ma wpływać na kształtowanie estetyki krajobrazu. 
Ocena, czy funkcja ta jest faktycznie realizowana, jest jednak niemożliwa z kilku powodów. Przede wszystkim zbyt krótki okres obowiązywania przepisów uniemożliwia jej dokonanie - w zaledwie kilku gminach weszła w życie uchwała w sprawie wprowadzenia opłaty reklamowej. Taki stan rzeczy spowodowany jest m.in. brakiem obowiązujących uchwał dotyczących małej architektury, które - jak już akcentowano - są aktami prawa miejscowego o charakterze fakultatywnym.

Analiza rozwiązań prawnych dotyczących opłaty reklamowej pozwala również na ogólną konstatację o szerokim zakresie władztwa daninowego gminy, zwłaszcza w zakresie kształtowania zasad wymiaru oraz poboru opłaty, co należy ocenić pozytywnie. Niektóre z regulacji należy jednak uznać za nieprecyzyjne, powodujące rozbieżności interpretacyjne. Nowelizacji powinny podlegać zwłaszcza przepisy dotyczące zaliczania opłaty reklamowej na poczet podatku od nieruchomości. Reasumując, należy stwierdzić, że opłata reklamowa jest daniną publiczną o niejednorodnym charakterze, która powinna być stałym elementem polityki tak podatkowej, jak i planistycznej gminy.

\section{Literatura}

Adam L., Mazurkiewicz M., Opłaty, w: System instytucji prawno-finansowych PRL, t. III, red. M. Weralski, Wrocław-Warszawa-Kraków-Gdańsk-Łódź 1985.

Antonów D., Charakter prawny opłaty reklamowej, „Finanse Komunalne” 2017, nr 1-2. Borszowski P., Stelmaszczyk K., Komentarz do ustawy o podatkach i opłatach lokalnych, w: Podatki i oplaty lokalne. Podatek rolny. Podatek leśny. Komentarz, Lex 2016.

Brzezicki T., Kara za niezgodne z prawem umieszczenie reklamy, „Przegląd Podatkowy” 2016, nr 8.

Gliniecka J., Opłaty publiczne w Polsce. Analiza prawna i funkcjonalna, BydgoszczGdańsk 2007.

Hadel M., Oplata reklamowa jako instrument ksztaltowania gminnej polityki przestrzennej, „Finanse Komunalne” 2016, nr 7-8.

Konstytucja Rzeczypospolitej Polskiej. Komentarz, red. M. Haczkowska, Lex 2014.

Krzywoń A., Podatki i inne daniny publiczne w orzecznictwie Trybunatu Konstytucyjnego. Najnowsze tendencje, „Przegląd Sejmowy” 2012, nr 1.

Nałęcz A., Estetyka przestrzeni publicznej w samorządzie terytorialnym, „Samorząd Terytorialny" 2015, nr 11.

Pahl B., Podatki i optaty lokalne. Teoria i praktyka, Lex 2017.

Ruśkowski E., Salachna J., Ustawa o dochodach jednostek samorzadu terytorialnego. Komentarz, Warszawa 2004. 
Ustawa krajobrazowa. Komentarz do przepisów wprowadzonych w zwiazku ze wzmocnieniem narzędzi ochrony krajobrazu, red. A. Fogel, Warszawa 2016.

Wronkowska S., Zieliński M., Komentarz do zasad techniki prawodawczej z dnia 20 czerwca 2002 r., Warszawa 2012.

\section{Akty prawne}

Obwieszczenie Ministra Finansów z dnia 25 lipca 2018 r. w sprawie górnych granic stawek kwotowych podatków i opłat lokalnych na rok 2019 (MP z 2018 r., poz. 745).

Ustawa z dnia 12 stycznia 1991 r. o podatkach i opłatach lokalnych (tekst jedn. Dz.U z 2018 r., poz. 1445 z późn.zm.).

Ustawa z dnia 2 kwietnia 1997 r. Konstytucja Rzeczypospolitej Polskiej (Dz.U. nr 78, poz. 483 z późn.zm.).

Ustawa z dnia 24 kwietnia 2015 r. o zmianie niektórych ustaw w związku ze wzmocnieniem instrumentów ochrony krajobrazu (Dz.U. poz. 774 z późn.zm.).

Ustawa z dnia 27 marca 2003 r. o planowaniu i zagospodarowaniu przestrzennym (tekst jedn. Dz.U. z 2018 r., poz. 1945).

Ustawa z dnia 29 sierpnia 1997 r. Ordynacja podatkowa (tekst jedn. Dz.U. z 2018 r., poz. 800 z późn. zm.).

\section{Orzeczenia}

Wyrok NSA 24 marca 2009 r., sygn. II GSK 812/08, Lex nr 529874.

Wyrok NSA z 12 grudnia 2018 r., sygn. II FSK 1897/18, www.nsa.gov.pl.

Wyrok NSA z 20 czerwca 2017 r., sygn. IFSK 997/15, LEX 2337592.

Wyrok TK z 16 marca 2010r., sygn. K 24/2008, OTK-A 2010, nr 3, poz. 22.

Wyrok WSA z 11 sierpnia 2017 r., sygn. IISA/Łd 523/17, Lex nr 2353893.

Wyrok WSA z 12 marca 2012 r., sygn. II SA/Bd 1373/11, www.nsa.gov.pl.

Wyrok WSA z 19 lutego 2009 r., sygn. I SA/Kr 1106/08, www.nsa.gov.pl.

Wyrok WSA z 20 maja 2008 r., sygn. II SA/Wr 204/08, www.nsa.gov.pl.

Wyrok WSA z 25 sierpnia 2016 r., sygn.VI SA/Wa 554/16, Lex nr 2185936.

Wyrok WSA z 6 grudnia 2006 r., sygn. II SA/Gl 662/06, www.nsa.gov.pl.

Wyrok WSA z 6 lutego 2013 r., sygn. III SA/Po 1124/12, www.nsa.gov.pl. 


\title{
LEGAL NATURE OF THE ADVERTISING FEE AND IST CONSTRUCTION ELEMENTS
}

\begin{abstract}
Summary
In 2015 the catalogue of public levies was extended to cover the advertising fee. The legal basis for its application was specified in the law on local taxes and fees. It is a commune own revenue, where the commune was equipped with a wide array of tax authority in terms of shaping statutory components of this levy. The aim of this study in to define the legal character of the advertising fee and its structural elements, taking into account the principles of the extent and collection of the performance in question. The systematics of the study were determined by the outlined research field. Subsequently, general questions were presented as well as an in-depth analysis of the applicable legal regulations. Against this background the de lege lata and the de lege ferenda conclusions were drawn.
\end{abstract}

Keywords: public tribute, advertising fee and its construction elements 